\title{
Pernikahan di Bawah Umur Akibat Hamil di Luar Nikah dan Dampak Psikologis Pada Anak di Desa Makrampai Kalimantan Barat
}

\author{
Asman \\ Institut Agama Islam (IAI) Sultan Muhammad Syafiuddin Sambas \\ Kalimantan Barat \\ raja.asman86@gmail.com
}

\begin{abstract}
This article aims to learn more about marriage in an aged wawah because of an extramarital pregnancy and the psychological impact on children in the village of Makrampai West Kalimantan. This study uses a qualitative method with a phenomenological approach, namely observations in the field, the authors want to describe how the attention of the people of Makrampai Village in Tebas Subdistrict to underage marriages due to pregnancy out of wedlock itself. From the results of this study it was found that underage marriages in Makrampai Village came from a background of lack of parental attention to their biological children so that their children fell into promiscuity which cannot be changed so that the future of children is damaged and the educational background of parents is also very influential towards the education of children at home. Underage marriage has many impacts on the perpetrator, including depression, anxiety, fear and stress which are the effects of underage marriage in Makrampai Village, Tebas District, Sambas Regency.
\end{abstract}

Keywords: Underage marriage, extramarital pregnancy, psychological impact

\begin{abstract}
Abstrak
Penelitian ini bertujuan untuk mempelajari lebih lanjut tentang Pernikahan di wawah umur karena Kehamilan di luar pernikahan dan dampak psikologi terhadap anak di desa Makrampai Kalimantan Barat. Penelitian ini menggunakan metode kualitatif dengan pendekatan fenomenologis yaitu pengamatan di lapangan, penulis ingin menggambarkan bagaimana perhatian masyarakat Desa Makrampai di Kecamatan Tebas terhadap pernikahan di bawah umur karena kehamilan di luar nikah itu sendiri. Dari hasil penelitian ini ditemukan bahwa pernikahan di bawah umur di Desa Makrampai berasal dari latar belakang kurangnya perhatian orang tua kepada anak kandungnya sehingga anak mereka jatuh ke dalam pergaulan bebas yang tidak dapat diubah sehingga masa depan anak rusak dan latar belakang pendidikan orang tua juga sangat berpengaruh terhadap pendidikan anak-anak di rumah. Pernikahan di bawah umur memiliki
\end{abstract}

Al-Istinbath : Jurnal Hukum Islam Vol. 4, No. 1, 2019; 79-100

p-issn: 2548-3374; e-issn: 2548-3382; DOI: 10.29240/jhi.v4i1.784

Available online at: http://journal.staincurup.ac.id/index.php/alistinbath 
banyak dampak pada pelaku, termasuk depresi, kecemasan, ketakutan dan stres yang merupakan dampak dari pernikahan di bawah umur di Desa Makrampai, Kecamatan Tebas, Kabupaten Sambas.

Kata kunci: pernikahan di bawah umur, hamil di luar nikah, dampak psikologis

\section{Pendahuluan}

Manusia diciptakan dengan berpasang-pasangan pria dan wanita yang secara kodrat mempunyai peran sebagai makhluk pribadi dan juga makhluk sosial. Dalam kehidupannya sebagai makhluk sosial manusia yang satu tidak biasa terlepas dari manusia yang lain dalam arti manusia selalu membutuhkan manusia yang lain atau lazim disebut dengan sosialisasi. Kebutuhan manusia sebagai makhluk sosial melahirkan rasa keterkaitan dan dorongan-dorongan untuk saling berhubungan satu sama lain, kemudian untuk sama-sama memenuhi kebutuhan hidupnya dan untuk menikmati kepuasannya, terkait hal ini harus terjalin dalam satu bentuk keluarga yang diikat dengan tali pernikahan.

Kedua pasangan itu pria dan wanita, baik segi fisik maupun biologis mempunyai sifat yang berbeda, secara biologis tersebut kedua mahluk tersebut saling membutuhkan satu sama lain sehingga diciptakan pasangan dan berjodoh secara harfiah disebut dalam Islam adalah perkawinan. Pernikahan merupakan sunnatullah yang berlaku pada mahluk Tuhan. ${ }^{1}$ Pernikahan merupakan suatu ikatan kehidupan bersama pria dan wanita yang dihalalkan Allah SWT, untuk mendapatkan kebahagiaan dan kesejahteraan serta anak dan keturunan yang shaleh dan shalehah. ${ }^{2}$

Pernikahan merupakan suatu yang sangat manusiawi, karena pernikahan sesungguhnya sesuai dengan fitrah manusia yang sejalan dengan al-Qur'an dan sunah Nabi saw. Pengertian fitrah disini adalah sesungguhnya Allah telah membekali setiap diri manusia dengan hawa nafsu yang cenderung menyukai serta mencintai lawan jenisnya. Islam menilai dan menetapkan bahwa pernikahan adalah cara menyempurnakan pelaksanaan ajaran Agama3. Dalam alQur'an memandang pernikahan sebagai salah satu tanda dari tanda-tanda kekuasaan Allah SWT. Sama seperti pencipta langit dan bumi, dan penciptaan manusia sebagaimana Allah berfirman dalam surat ar-Rum, [30]: 21:

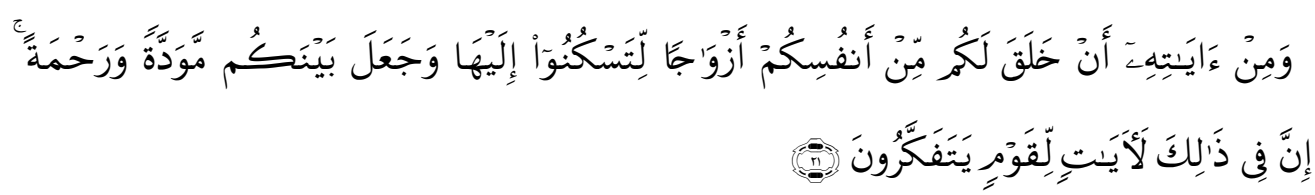

\footnotetext{
${ }^{1}$ Sayyid Sabiq, Fiqih Sunnah, (Terj) Moh Thalib jilid 6,Cet I (Jakarta: Al-Ma'arif,1990), hlm. 9 .

${ }^{2}$ Hasan Basri, Merawat Cinta Kasih (Yogyakarta: Pustaka Pelajar, 1996), hlm. 130.

${ }^{3}$ Mahalli A. Madjab, Menikablab Engkau Menjadi Kaya (Kado Pernikahan Untuk Pasangan Muda), (Yogyakarta: PT Mitra Pustaka, 2006), hlm. 6.
} 
Dan di antara tanda-tanda kekuasaan-Nya ialah dia menciptakan untukmu isteri-isteri dari jenismu sendiri, supaya kamu cenderung dan merasa tenteram kepadanya, dan dijadikan-Nya diantar mu rasa kasih dan sayang. Sesunggubnya pada yang demikian itu benar-benar terdapat tanda-tanda bagi kaum yang berfikir.

Pernikahan yang sah dalam kehidupan rumah tangga dapat dibina dengan suasana aman, damai dan sejahtera. Hal ini sesuai dengan tujuan pernikahan itu sendiri, yaitu membentuk keluarga yang bahagia dan kekal berdasarkan ajaran Islam yaitu sakinah. Sehingga dapat mewujudkan tujuan pernikahan secara baik dalam membina rumah tangga, oleh karena itu dalam peraturan perundangan dijelaskan bahwa batas umur untuk melangsungkan pernikahan. Ketentuan batas umur tersebut dalam pasal 7 ayat I UU Nomor. I Tahun 19974 yang berbunyi "bahwa pernikahannya diijinkan jika pihak pria sudah mencapai umur 19 tahun pihak wanita mencapai umur 16 tahun". Dari batas umur pernikahan tersebut dapat ditafsirkan bahwa UU Nomor. I Tahun 1974 tidak menghendaki pernikahan yang dilakukan oleh mereka yang berusia di bawah ketentuan tersebut atau melakukan pernikahan di bawah umur begitu jaga di dalam Kompilasi Hukum Islam ada batasan umur dalam pernikahan menurut Islam dalam pasal 15 yang isinya "bahwa untuk kemaslahatan keluarga dan rumah tangga pernikahan hanya boleh dilakukan calon mempelai yang telah mencapai umur yang ditetapkan pasal 7 UU No. I Tahun 1974 yakni calon suami sekurang-kurangnya berumur 19 tahun dan calon istri sekurang-kurangnya 16 tahun". Penyebab pernikahan di bawah umur ini dipengaruhi oleh berbagai macam faktor, misalnya rendahnya pendidikan mereka sangat mempengaruhi pola pikir mereka dalam memahami dan mengerti tentang hakikat dan tujuan dalam pernikahan, pergaulan bebas, pengaruh teknologi dan faktor ekonomi, sosial maupun lingkungan tempat mereka tinggal juga bisa menjadi penyebab pernikahan di bawah umur ini, dalam kehidupan rumah tangga pasti tidak luput dari permasalahan-permasalahan. Salah satu penyebab utama permasalahan dalam rumah tangga adalah pasangan yang belum dewasa dan belum siap untuk menakhodai rumah tangga.

Faktor ketidak dewasa ini lebih nyata terdapat dalam pernikahan di bawah umur. Dilihat dari segi psikologi perkembangan, dengan makin bertambahnya umur seseorang, diharapkan akan lebih masak, akan lebih matang lagi psikologisnya. ${ }^{4}$ Memang kalau kita lihat tingkat kedewasaan pribadi seseorang tidak tergantung pada umur, tetapi masa remaja adalah masa peralihan dari masa kanak-kanak menuju masa dewasa. Pada masa remaja ini umumnya remaja belum memiliki kepribadian yang mantap dan kematangan berfikir. Perkawinan di bawah umur tidaklah menguntungkan bahkan jelas merugikan kaum perempuan, dalam usia yang masih muda, remaja putri dituntut untuk

${ }^{4}$ Walgito, Bimo, Bimbingan dan Konseling Perkawinan, (Yogyakarta: Yayasan Penerbitan Fak. Psikologi. UGM, 2000), hlm.28. 
mengurus rumah tangga, melayani suami, harus mengandung dan melahirkan, kemudian merawat dan membesarkannya. Sedangkan mengandung dan melahirkan pada usia muda sangat beresiko tinggi bagi kesehatan, bagi ibu muda bisa menimbulkan kangker leher rahim dan rawan keguguran. Pernikahan yang masih muda juga banyak mengundang masalah yang tidak diharapkan dikarenakan segi psikologisnya belum matang khususnya bagi perempuan. ${ }^{5}$

Menurut Basri dalam bukunya yang berjudul merawat cinta kasih mengatakan secara fisik biologis yang normal seorang pemuda atau pemudi telah mampu mendapatkan keturunan, tetapi dari segi psikologis remaja masih sangat hijau dan kurang mampu mengendalikan bahtera rumah tangga di samudra kehidupan. Berapa banyak keluarga dan pernikahan terpaksa mengalami nasib yang kurang beruntung dan bahkan tidak berlangsung lama karena usia terlalu muda dari para pelakunya, baik salah satu atau keduanya. ${ }^{6}$ Dan pernikahan yang terlalu muda juga bisa menyebabkan neuritis depresi karena mengalami proses kekecewaan yang berlarut-larut dan karena ada perasaan-perasaan tertekan yang sangat berlebihan. Kematangan sosial dan ekonomi dalam pernikahan sangat diperlukan karena merupakan penyangga dalam memutarkan roda keluarga sebagai akibat perkawinan. Pada umumnya umur yang masih muda belum mempunyai pegangan dalam hal sosial dan ekonomi. Padahal setiap individu tersebut dituntut untuk memenuhi kebutuhan keluarga. Untuk wujud kepedulian terhadap Desa Makrampai maka dari itu Kantor Urusan Agama Bagian BP4 Kecamatan Tebas Kabupaten Sambas harus mengadakan penyuluhan bertemakan tentang pernikahan di bawah umur yang ditujukan kepada orang tua dan remaja, yang di programkan dan ditempatkan di Kantor Desa Makrampai.

\section{Pembahasan}

\section{Pengertian Pernikahan}

Pernikahan di bawah umur merupakan salah satu istilah yang dibentuk dari kata yaitu kata 'pernikahan'. Kata pernikahan dalam bahasa Indonesia adalah kata benda (nomina) yang merupakan kata serapan dari bahasa Arab yaitu nakaha, yankibu, nikahan. Selain itu nikah menurut bahasa al-jam'u dan al-dhamu yang artinya kumpul. ${ }^{7}$ Makna nikah (zawaj) bisa diartikan dengan aqdu al-tazwij yang artinya akad nikah. Definisi yang hampir sama dengan di atas Rahmad Hakim mengemukakan bahwa, kata nikah berasal dari bahasa Arab nikâhun yang merupakan masdar atau asal kata kerja (fi'il mâdbi) nikaha, sinonimnya tazamwaja kemudian diterjemahkan dalam bahasa Indonesia sebagai perkawinan. ${ }^{8}$

${ }^{5}$ Ibid., 20.

${ }^{6}$ Hasan Basri, Merawat Cinta Kasih,76

${ }^{7}$ Muhammad Jawad Mughniyyah, Al-Ahwâl Al-Syâkkhsîyyah. Beirut: Dâr Al Kutub Al 'Ilmiyâh,tt. terjemah. Sulaiman Al-Mufarraj.

8 Tihami Sohari Sahrani, Fikih Munakahat: Kajian Fikih Nikah Lengkap, Jakarta: Rajawali Pers, 2010), hlm. 7. 
Menurut dalam Kamus Besar Bahasa Indonesia (KBBI), nikah (pernikahan atau perkawinan adalah perjanjian antara laki-laki dan perempuan untuk bersuami istri (dengan resmi).9Mengenai definisi atau konsep pernikahan di bawah umur setelah di kaji dari beberapa literatur yang ada dan beberapa pendapat ahli ternyata konsepnya berbeda-beda. Beberapa konsep pernikahan di bawah umur yang penulis kemukakan sebagai berikut: Menurut Sri Rahayu Hadiutomo, usia muda atau remaja secara global dimulai sejak umur 12 tahun dan berakhir usia 21 tahun dan menurut Muhammad Fauzhil Addhim memaknai pernikahan dini yakni pernikahan yang dilakukan dimasa perkuliahan atau pernikahan remaja. ${ }^{10}$

Jika pernikahan di bawah umur dimaknai dengan pernikahan dalam usia remaja maka yang termasuk pernikahan di bawah umur adalah pernikahan yang dilakukan pasangan yang berusia 11 sampai 24 tahun dengan pertimbangan sebagai berikut: ${ }^{11}$

a. Usia 11 tahun adalah usia dimana pada umumnya tanda-tanda seksual sekunder mulai Nampak (kriteria fisik).

b. Umumnya masyarakat Indonesia yang berumur 11 tahun sudah dianggap baligh baik menurut adat maupun menurut agama sehingga masyarakat tidak memperlakukan mereka sebagai anak-anak (kriteria sosial). Pada usia tersebut mulai ada tanda-tanda penyempurnaan perkembangan jiwa.

c. Usia 24 tahun merupakan batas maksimum untuk memberi kesempatan mereka mengembangkan jiwa setelah sebelumnya masih bersama dengan orang tua.

Pernikahan di bawah umur juga dilihat dalam kitab-kitab fiqih baru dengan istilah Az-Zawâj Al-Mubakkir. ${ }^{12}$ Istilah ini mengandung pengertian hamil, jika tidak terjadi indikasi-indikasi tersebut, maka baligh atau balighah ditentukan berdasarkan usia. Abu Hanifah berpendapat bahwa usia baligh bagi laki-laki adalah 18 tahun dan untuk perempuan 17 tahun. Sementara Abu Yusuf Muhammad bin Hasan bin As-Syafi'i berpendapat bahwa usia 15 tahun baik untuk laki-laki dan perempuan. ${ }^{13}$ Sedangkan batas batas usia pernikahan ini dapat dilihat dalam pasal 7 ayat (1) Undang-Undang No. 7 tahun 1974 yaitu pernikahan hanya diizinkan jika pihak pria telah mencapai 19 tahun dan pihak wanita 16 tahun. Dari pasal di atas ini bahwa pernikahan yang dilakukan di bawah umur melanggar undang-undang perkawinan. Konsekuensinya

9 Anonimous, Kamus Besar Bahasa Indonesia, (Jakarta: Balai Pustaka, Departemen Pendidikan dan kebudayaan, 1994), hlm. 456.

${ }^{10}$ Bety, Pernikahan Dini, (Palembang: IAIN RADEN FATAH, 2013), hlm. 16.

${ }^{11}$ Abu Al-Ghifari, Pernikahan dini Dilema Generasi Extravaganza, (Bandung:Rineka Cipta, 2002), hlm. 23.

${ }^{12}$ Muhammad Husein, Fiqih Perempuan, (Yogyakarta: LKIS, 2007), hlm. 67.

${ }^{13}$ As-Syarbini Al-Khatîb, Muqhnî Al-Mubtâj; (Beirut: Dâr ihya At-Turusi Al-Arabî), Juz II, hlm. 166. 
pernikahan tersebut tidak tercatat, pernikahan yang tidak tercatat adalah pernikahan di bawah umur dianggap tidak mempunyai kekuatan hukum menurut undang-undang. Artinya, menurut hukum Negara pernikahan tersebut dianggap tidak ada. Terkecuali sebelum pernikahan terlebih dahulu mendapatkan dispensasi dari Pengadilan Agama bagi agama Islam dan Pengadilan Negeri bagi Non Islam.

Dari penjelasan di atas dapat dipahami bahwa batasan usia pernikahan di bawah umur sangat variatif. Ada yang berpendapat bahwa pernikahan di bawah umur adalah pernikahan yang dilakukan di bawah 15 tahun, sebagian berpendapat di bawah 17 sampai 18 tahun dan yang lain berpendapat di bawah 20-an tahun dan sebagian lagi di bawah 24 tahun. Namun jika dikaitkan dengan undang-undang perkawinan maka yang termasuk pernikahan di bawah umur pernikahan di bawah umur yaitu pernikahan yang dilakukan pasangan 19 tahun, 19 tahun bagi suami dan di bawah 16 tahun bagi istri. Pernikahan menurut ajaran Islam memiliki arti yang sangat penting, karena: ${ }^{14}$

a. Pernikahan merupakan fitrah manusia, artinya setiap manusia yang sehat, baik jasmani maupun rohani memerlukan perkawinan sebagai pemenuhan kebutuhan hidupnya sebagai manusia.

b. Pernikahan mengundang makna ibadah, karena pernikahan dalam ajaran Islam merupakan salah satu sunah Rasul yang dapat mengikat kualitas keimanan dan ibadah kepada Allah.

c. Pernikahan merupakan awal kehidupan seseorang, baik laki-laki maupun perempuan yang membentuk keluarga sebagai proses regenerasi yang akan melanjutkan kehidupan yang akan merusak perjuangan di muka bumi.

Menurut Undang-Undang Nomor 1 tahun 1974 pernikahan adalah ikatan lahir batin antara seorang pria dan seorang wanita sebagai suami istri dengan tujuan membentuk keluarga yang bahagia dan kekal berdasarkan Ketuhanan Yang Maha Esa. ${ }^{15}$ Adapun syarat sah pernikahan itu apabila telah memenuhi syarat-syarat yang telah ditentukan oleh Undang-Undang maupun hukum Islam. Dalam pasal 2 ayat (1) Undang-undang Perkawinan menyatakan bahwa pernikahan sah apabila dilakukan menurut hukum masing-masing. Sedangkan menurut hukum perkawinan Islam yang dijadikan sah dan tidaknya pernikahan itu adalah dipenuhinya syarat-syarat dan rukun pernikahan berdasarkan hukum agama Islam. Dalam hal ini hukum Islam mengenal perbedaan antara syarat dan rukun pernikahan. Rukun merupakan sebagian hakikat pernikahan itu sendiri dan jika tidak dipenuhi maka pernikahan tidak akan terjadi. Rukun pernikahan tersebut antara lain ${ }^{: 16}$

a. Adanya kedua mempelai

\footnotetext{
${ }^{14}$ A. Toto Suryanah, AF, Ibadab Praktis, (Bandung: Sinar Harapan, 1995), hlm. 77.

${ }^{15}$ Bimo Walgito, Bimbingan dan Konseling Perkawinan, hlm. 35.

${ }^{16}$ Ibid., 36
} 
b. Adanya wali dari pihak mempelai

c. Adanya dua orang saksi

d. Adanya ijab kabul

e. Adanya mahar antara lain:

Adapun syarat pernikahan menurut UU Perkawinan No.1 Tahun 1974

a. Perkawinan di lakukan menurut hukum agama dan kepercayaan, pasal 2 ayat (1).

b. Tiap pernikahan harus dicatat menurut peraturan perundang-undangan yang berlaku, pasal 2 ayat (2)

c. Perkawinan laki-laki yang sudah yang sudah mempunyai istri harus mendapat izin dari pengadilan, pasal 3 ayat (2) dan pasal 27 ayat (2).

d. Untuk melangsungkan perkawinan seorang yang belum mencapai umur 21 tahun harus mendapat izin kedua orang tua. Pasal 6 ayat (2). Bila orang tua berhalangan, izin diberikan oleh pihak lain yang ditentukan dalam undangundang pasal 6 ayat (2 dan 5).

e. Perkawinan hanya diijinkan jika pihak pria sudah mencapai umur 19 tahun, dan pihak wanita sudah mencapai umur 16 tahun. Pasal 7 ayat (1), ketentuan ini tidak bertentangan dengan Islam, sebab setiap masyarakat dan setiap zaman berhak menentukan batas-batas umur bagi perkawinan selaras dengan sistem terbuka yang dipakai. Harus ada persetujuan antara kedua calon mempelai kecuali apa bila hukum menentukan lain. Pasal 6 ayat (1), hal ini untuk menghindarkan paksaan bagi calon mempelai dalam memilih istri atau suami.

\section{Batasan Minimal dalam Pernikahan}

Masalah penentuan usia dalam Undang-Undang Perkawinan maupun dalam Kompilasi Hukum Islam (KHI), memang bersifat ijtihâdiyah, sebagai usaha pembaharuan pemikiran fiqih yang telah dirumuskan. Namun demikian, apabila dilacak referensi syar'inya mempunyai landasan kuat. Misalnya isyarat Allah dalam surat an-Nisâ' [4]: 9:
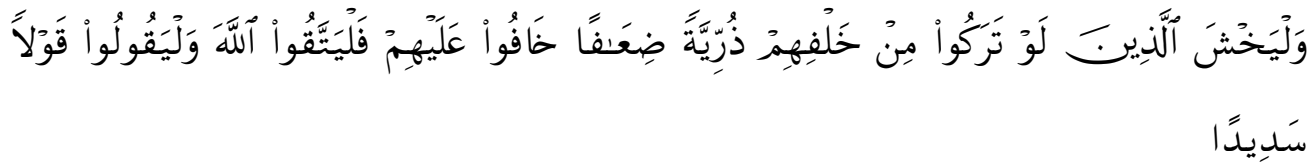

Dana hendaklah takut kepada Allah orang-orang yang seandainya meninggalkan di belakang mereka anak-anak yang lemah, yang mereka khawatirkan terhadap (kesejabteraan) mereka. Oleh sebab itu hendaklah mereka bertakwa kepada Allah dan bendaklah mereka mengucapkan perkataan yang benar.

${ }^{17}$ Undang-Undang No. 1 Tahun 1974 Tentang Perkawinan dan Kompilasi Hukum Islam. Cet. 1 (Surabaya: Sinarsindo Utama, 2015), hlm. 35 
Ayat tersebut masih bersifat umum, tidak secara langsung menunjukkan bahwa perkawinan yang dilakukan oleh pasangan dibawah umur di bawah ketentuan yang diatur melalui Undang-Undang No. 1 Tahun 1974 akan menghasilkan keturunan yang dikhawatirkan kesejahteraannya. Akan tetapi berdasarkan pengamatan menyatakan rendahnya usia kawin, lebih banyak menimbulkan hal-hal yang tidak sejalan dengan misi dan tujuan perkawinan yaitu terwujudnya ketentraman dalam rumah tangga berdasarkan kasih sayang. Tujuan tersebut tentu akan sulit terwujud, apabila masing-masing mempelai belum masak jiwa dan ragam. Kematangan dan integritas pribadi yang stabil akan sangat berpengaruh di dalam menyelesaikan setiap problema yang muncul dalam menghadapi liku-liku dan badai rumah tangga yang menyebabkan banyaknya perceraian cenderung didominasi karena akibat perkawinan dalam usia muda. ${ }^{18}$

Dasar pemikiran tidak adanya batas umur pasangan yang akan kawin itu kiranya sesuai dengan pandangan umat ketika itu tentang hakikat perkawinan. Menurut penulis pendangan mereka terhadap pernikahan itu tidak dilihat dari segi hubungan kelamin, tetapi dari segi pengaruh dalam menciptakan hubungan yang bahagia. Secara metodologis, langkah penentuan usia kawin didasarkan kepada metode marshalahat mursalah.

Adapun hadis Nabi adalah hadis dari Abdullah ibn Masud Muttafaq Alaih yang bunyinya: ${ }^{19}$

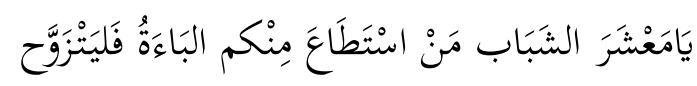

Wahai para pemuda siapa di antara kamu telah mempunyai kemampuan dalam persiapan, maka kawinlah.

Batas usia dewasa sebagaimana dapat dipahami dari ayat al-Quran dan Hadits Nabi tersebut di atas secara jelas diatur dalam Undang-Undang Perkawinan Pasal 7 dengan rumusan sebagai berikut: ${ }^{20}$

a. Perkawinan hanya di izinkan jika pihak pria sudah mencapai umur 19 tahun dan pihak wanita sudah mencapai umur 16 tahun

b. Dalam hal penyimpangan terhadap ayat (1) pasal ini dapat meminta dispensasi kepada pengadilan Agama atau pejabat yang ditunjuk oleh kedua orang tua pihak pria maupun wanita.

Bedanya jika kurang dari umur 19 tahun yang diperlukan izin orang tua dan jika kurang dari umur 16 tahun perlu dispensasi pengadilan.Ini dikuatkan pasal 15 ayat 2, 21 dalam Kompilasi Hukum Islam.

${ }^{18}$ Ahmad Rofiq, Hukum Perdata Islam di Indonesia, (Jakarta: Rajawali Press, 2015), hlm. 60.

19 Amir Syarifuddin, Hukum Perkawinan Islam di Indonesia: Antara Fiqih Munakahat dan Undang-undang Perkawinan, (Jakarta: Prenada Media Group, 2014), hlm. 67.

${ }^{20}$ Ibid., 67.

${ }^{21}$ Bagai calon mempelai yang belum mencapai umur 21 tahun harus mendapati izin 
Adapun prosedur untuk mendapatkan dispensasi dimaksud dapat dilihat dalam peraturan Menteri Agama Nomor 3 Tahun 1975 Pasal (13), yang diatur sebagai berikut: ${ }^{22}$

a. Apabila seorang calon suami belum mencapai umur 19 tahun dan calon istri belum mencapai umur 16 tahun hendak melangsungkan pernikahan harus mendapat dispensasi dari Pengadilan Agama.

b. Permohonan dispensasi nikah bagi mereka tersebut pada ayat (1), diajukan kedua orang tua pria maupun wanita kepada pengadilan Agama yang mewilayahi tempat tinggalnya.

c. Pengadilan Agama setelah memeriksa dalam persidangan dan berkeyakinan bahwa terdapat hal yang memungkinkan untuk memberikan dispensasi tersebut, maka Pengadilan Agama memberikan dispensasi nikah dengan suatu penetapan.

d. Penetapan itu dibuat dan diberikan kepada pemohon untuk memenuhi persyaratan melangsungkan pernikahan.

Kompilasi Hukum Islam mempertegas persyaratan yang terdapat dalam UU Perkawinanan dengan rumusan sebagai berikut: Untuk kemaslahatan keluarga dan rumah tangga, perkawinan hanya boleh dilakukan calon mempelai yang telah mencapai umur yang di tetapkan dalam Pasal 7 Undang-Undang No.1 Tahun 1974,yakni calon suami sekurang-kurangnya berumur 19 tahun dan calon istri sekurang-kurangnya berumur 16 tahun. ${ }^{23}$

Penjelasan persyaratan di atas menyatakan dalam al-Quran maupun hadits serta Undang-Undang perkawinan ini untuk melangsungkan Pernikahan, yaitu kemampuan persiapan pernikahan. Kemampuan dan persiapan untuk perkawinan ini hanya dapat terjadi bagi orang yang sudah dewasa. Dalam salah satu persyaratan yang akan melangsungkan perkawinan tersebut di atas terdapat keharusan persetujuan kedua belah pihak untuk melangsungkan perkawinan. Persetujuan dan kerelaan itu tidak akan timbul dari seseorang yang masih kecil hal itu mengandung berarti bahwa pasangan yang diminta persetujuannya itu haruslah sudah dewasa.

Menurut Muhammad Yusuf Hanifah, dalam pidatonya dalam pengukuhan pada 19 September 1978 seperti yang dikutip oleh T. Jafizham, dari sudut genealogi wanita kawin pada usia muda atau usia belasan tahun

sebagaimana yang diatur dalam pasal 6 ayat (2), (3), (4) dan (5) UU No. 1 Tahun 1974.Lihat juga Undang-Undang Perkawinan Nomor 1 Tahun 1974 Tentang Perkawinan dan Kompilasi Hukum Islam.Cet.1, 4.

22 Bety, Pernikahan Dini, hlm.19.

${ }^{23}$ Mediaya Rafeldi, Kompilasi Hukum Islam dan Undang-undang Perkawinan, Wakaf, dan penyelenggaraan Haji, (Jakarta: ALIKA, 2016), hlm. 65. 
sebenarnya dapat menimbulkan beberapa kerugian, diantaranya: ${ }^{24}$

Pada usia 16 tahun seorang wanita sedang mengalami pubertas yaitu masa peralihan dari anak-anak menjadi dewasa, malahan ada diantara mereka yang baru pertama kali mendapat haid atau manarehe. Walaupun usia dapat haid rata-rata 12,5 tahun tapi variasinya berbeda, yaitu antara 10-16 tahun. Pada masa pubertas gadis remaja sedang mengalami perubahan pada fisik, menuju pada seorang dewasa yang bertanggung jawab, percaya pada diri sendiri, bebas dan ingin berdiri sendiri. Proses ini memerlukan waktu beberapa tahun hingga cukup dewasa, sehingga pada usia 16 tahun seseorang wanita sebenarnya belum siap fisik dan mentalnya untuk menjadi ibu rumah tangga.

Perkawinan di bawah umur 16 tahun wanita tersebut paling tinggi baru memperoleh pendidikan selama 9 tahun (paling tinggi SLTP) dan sebagian besar putus sekolah setelah berumah tangga. Pendidikan pada wanita mempengaruhi berbagai hal diantaranya pendidikan anak-anak dan keberhasilan program KB serta kependudukan.

Perkawinan di bawah umur berarti memberi peluang kepada wanita belasan tahun untuk menjadi hamil dengan resiko tinggi (high risk pregnancy) pada kehamilan belasan tahun (teen age pregnancy) komplikasi-komplikasi pada ibu dan anak seperti anemia, preaelamasi, elam, abortus, partus pracmaturus, kematian pra netral, golongan 20 tahun ke atas. Hal ini telah diselidiki oleh para ahli berbagai Negara yang dilaporkan dalam population report No. 10, 1976.

Perkawinan di bawah umur berarti memperpanjang reproduksi, menarche masa kini lebih cepat dari 50 tahun yang lampau. Sedangkan menopause lambat karena faktor kesehatan umumnya. Dengan menunda perkawinan berarti memperpanjang masa antara dua generasi dan memperpendek masa reproduksi. Dengan menunda perkawinan, maka jelas pengaruhnya terhadap lajunya pertumbuhan penduduk.

Dilihat dari batas umur menyatakan bahwa, bolehnya seseorang menikah menurut Undang-Undang No. 1 tahun 1974 tentang perkawinan adalah umur 19 tahun bagi pria dan umur 16 tahun bagi wanita. Ada hal yang menarik dimana sebagian literature mengklaim pernikahan di bawah umur atau young marriage sebagai penyebab perceraian, studi gagal, sering terjadi pertengkaran dan ekonomi sulit.

\section{Pernikahan di Bawah Umur di Desa Makrampai Kecamatan Tebas Kabupaten Samba Provinsi Kalimantan Barat}

${ }^{24}$ Bety, Pernikahan Dini, hlm.7. 
Asas yang terkandung dalam undang-undang perkawinan salah satunya yang disebutkan adalah pendewasaan usia pernikahan artinya bahwa calon suami dan calon istri harus matang jiwa dan raganya serta siap melaksanakan pernikahan itu. Untuk mencapai maksud agar setiap pernikahan dilakukan pada usia dewasa. Maka para ahli menentukan syarat minimal usia perkawinan sebagaimana tercantum dalam undang-undang perkawinan pasal 7 ayat (1)yaitu, batas minimal bagi laki-laki umur19 tahun dan perempuan umur16tahun.Secara formal tidak diketemukan lagi data pernikahan di awah umur dari pengadilan agama, namun demikian bukan berarti bahwa tidak ada lagi pernikahan di bawah umur tapi di masyarakat Desa Makrampai menutupi kasus tersebut agar tidak terjadi pembicaraan di lingkungan masyarakat tersebut.

Menurut fakta di lapangan secara umum di Desa Makrampai yang memiliki dua dusun. Dalam pernikahan di bawah umur kebanyakan pihak wanita lebih muda dari pada pria, walaupun ada sebagian pria lebih muda dari pada wanita. Latar belakang kehidupan orang tua yang beragam dari kurang mampu sampai yang mampu, ada yang tidak mampu dengan alasan mengurangi beban yang ditanggung oleh orang tua dan yang mampu akibat pergaulan yang terlalu bebas sehingga orang tua tidak terkontrol dengan anak-anak. Tebas $^{25}$

Tabel data pernikahan di bawah umur di Desa Makrampai Kecamatan

\begin{tabular}{|c|c|c|c|c|c|c|}
\hline No. & \multicolumn{2}{|c|}{ Nama } & \multicolumn{2}{c|}{ Umur } & \multicolumn{2}{c|}{ Pendidikan } \\
\hline & Suami & Istri & Suami & Istri & Suami & Istri \\
\hline 1 & Yendi & Maya & 17 & 15 & SMP & SD \\
\hline 2 & Heri & Nonong & 18 & 15 & SMP & SD \\
\hline 3 & Zoro & Momok & 18 & 16 & SMP & SD \\
\hline 4 & Agus & Rena & 18 & 15 & SD & SD \\
\hline
\end{tabular}

\section{Faktor Penyebab Pernikahan di Bawah Umur}

Pada umumnya di dalam masyarakat, anak-anak yang menginjak usia dewasa akan berkembang dengan kondisi fisik, mentalitas dan sosialnya. Mereka bergaul dengan temannya dalam pergaulan itu mereka menemukan pasangan yang dirasakannya sesuai untuk dirinya. Perubahan pergaulan yang akrab tersebut kemudian menumbuhkan rasa cinta, yang pada akhirnya keduanya menginginkan pernikahan. Hal inilah yang terjadi di Desa Makrampai akibat pergaulan bebas seorang anak terutama anak perempuan yang mengakibatkan terjadinya cinta terlarang sehingga membuahkan hasil hamil di luar nikah, terjadilah putus sekolah tingkat SD dan SLTP.

Hal tersebut tidak terlepas dari kondisi sosial mereka yang bertempat KALBAR.

${ }^{25}$ Sumber data Pengamatan di Desa Makrampai Kecamatan Tebas Kabupaten Sambas 
tinggal di perkampungan. Dan kebanyakan mata pencaharian orang tuanya adalah petani, yang minimnya juga pendidikan agama terhadap orang tua sedikit sehingga latar belakang yang mempengaruhi pernikahan di bawah umur di Desa Makrampai Kecamatan Sambas Kabupaten Sambas Provinsi Kalimantan Barat. Momok (16 tahun), ${ }^{26}$ sebagai salah satu responden yang terlibat langsung menikah dalam usia di bawah umur, terjadinya pernikahan ini diakibatkan pergaulan bebas sehingga menyebabkan hamil di luar nikah sehingga tidak dapat melanjutkan ke sekolah tingkat atas. Dan responden lainnya kasusnya dampak percintaan sehingga tidak sabar untuk menikah dan ada yang sama seperti yang dialami oleh momok tersebut sehingga pernikahan di bawah umur lah yang terjadi.

Keadaan masyarakat perdesaan pada umumnya tingkat ekonominya rendah, sebab sebagian besar mayoritas mata pencaharianya adalah sebagai petani ataupun buruh tani atau bisa dikatakan hidup yang tidak memadai kadang dapat banyak kadang dapat sedikit. Hal ini dapat menentukan kelangsungan hidup rumahtangga dalam memenuhi kehidupan sehari-hari. Kenyataan di masyarakat Desa Makrampai yang anaknya terlibat dalam pernikahan di bawah umur termasuk dari golongan masyarakat ekonomi rendah dan menengah, setelah kejadian tersebut orang tua tersebut beranggapan lebih baik menikahkan anaknya dari pada menanggung malu di masyarakat akibat ulah anaknya sendiri dan sehingga dilakukan nikah di bawah tangan.

Kehidupan Masyarakat Desa Makrampai terutama orang tua setelah menikahkan anaknya mereka menyerahkan sepenuhnya anak perempuannya ke suami anaknya untuk menjalankan kehidupan berumah tangga dan tidak memikirkan dampak psikologi si anak tersebut. Oleh karena itu pernikahan adalah merupakan sesuatu yang suci dan luhur serta persiapan usia harus lebih matang sehingga bisa membina rumah tangga yang bahagia. Memang benar Islam menganjurkan untuk setiap muslim melaksanakan sunah Rasulullah dalam menganjurkan untuk setiap muslim melaksanakan pernikahan. Rasulullah sendiri melarang seseorang untuk membujang kecuali dengan alasan-alasan tertentu. Tetapi kenyataannya anak remaja sekarang pergaulan bebasnya sudah melampaui batas yang disebut Free sex (seks bebas) sehingga mengakibatkan terjadinya pernikahan di bawah umur yang seharus tidak diinginkan oleh orang tuanya.

Dengan demikian Desa Makrampai di kecamatan Tebas pernikahan anak di bawah umur sudah cukup berlangsung lama dilakukan. Untuk memberikan masukan-masukan supaya masyarakat lebih mengerti dengan dampak pernikahan di bawah umur itu harus ada pendamping dari orang tua dalam kehidupan berumah tangga sehingga tidak mengganggu psikologis anak. Perkawinan di bawah umur ini bagi masyarakat Desa Makrampai merupakan

${ }^{26}$ Momok (16 Tahun) salah satu responden pengamatan pernikahan di bawah umur di Desa Makrampai Kecamatan Tebas Kabupaten Sambas KALBAR 
alternatif terakhir untuk mengatasi suatu keadaan yang tidak diinginkan oleh semua pihak seperti halnya karena adanya pemikiran yang masih diwarnai dengan fitnah. Jadi menurut ukuran kedewasaan dalam pernikahan di bawah umur ini berhubungan erat dengan kematangan dan kemampuan wanita dan pria akan melangsungkan pernikahan. Walaupun anak tersebut belum siap mental untuk menikah dan seharusnya orang tua lebih menjaga dan mengontrol pergaulan anaknya tersebut.

Meskipun secara aturan, agama Islam tidak menentukan batas usia pernikahan, namun Islam memberikan batasan kemampuan bagi seorang yang sudah pantas dianjurkan untuk melaksanakan akan pernikahan dan harus menahan diri bagi yang belum mampu melaksanakan perkawinan prinsip ini berdasarkan Hadits Rasulullah Saw.

"Wahai para pemuda, barang siapa di antara kalian siap maka kawinlah. Karena sesungguhnya kawin lebih bisa menjaga pandangan mata dan lebih menjaga kemaluan. Bila tidak mampu melaksanakannya maka berpuasalah karena puasa bagi Nya adalah kendali".

Sabda Rasulullah Saw tersebut memberikan petunjuk, bahwa baik pria maupun wanita apabila belum mampu, dianjurkan untuk menunda pernikahan sampai mempunyai kemampuan mental, fisik, terutama bagi calon istri yang akan menghadapi kehamilan dan kelahiran. Faktor usia ibu muda yang hamil akan berpengaruh besar terhadap kualitas janin dan perkembangan anak selanjutnya dan juga berdampak terhadap psikologis si ibu. Berdasarkan uriaan di atas, tentang berbagai faktor yang menyebabkan perkawinan usia di bawah umur ini dapat dimengerti bahwa faktor orang tua sangat mendominasi terjadinya perkawinan usia di bawah umur baik itu karena pengaruh pendidikan, ekonomi dan sosial. Karena orang tua itu adalah sebagai pembentuk dan pembangun jiwa anak pertama kali sebelum anak mengenal dunia lain. Selain itu orang tua adalah orang yang paling dekat dengan anak-anak mereka dan rasa cinta serta tanggungjawab terhadap anaknya merupakan pemicu utama untuk selalu membahagiakan anak mereka menuju jalan yang penuh kebahagiaan, terutama dalam mengendalikan rumah tangga. Jadi untuk dapat melangsungkan pernikahan tidak terlepas adanya izin dari kedua orang tua, sebagai mana yang ditetapkan dalam Undang-Undang Perkawinan No. 1 tahun 1974 pasal 6 ayat 2.

Pernikahan di bawah umur pada umumnya belum memiliki kematangan jiwa dalam melangsungkan perkawinan, sehingga apabila mereka nikah, maka antara suami istri tersebut tidak dapat menjalankan hak dan kewajibannya secara baik sebagai suami istri di dalam kehidupan berumah tangga, dan akan menimbulkan kegoncangan karena hal tersebut telah menyimpang dari ketentuan yang ada. Pengabaian tugas seorang kepada orang lain merupakan penyebab utama terjadinya perselisihan dan pertengkaran yang akhirnya di dalam kehidupan rumahtangga tidak harmonis dan tidak sejahtera. Pernikahan usia dini 
biasanya dilakukan pada usia di bawah 20 tahun bagi wanita dan usia 25 tahun bagi laki-laki, mereka itu biasanya belum mempunyai pekerjaan yang menetap yang pada akhirnya akan menjadi beban kedua orang tua. Apabila sudah mempunyai anak hal ini akan menambah berat beban bagi orang tuanya.

\section{Dampak Psikologis Pernikahan di Bawah Umur Akibat Hamil di Luar Nikah}

Membina mahligai kehidupan rumahtangga pasti tidak luput dengan adanya permasalahan yang di hadapi. Salah satu penyebab utama adalah pasangan yang belum dewasa dan belum siap membina ramah tangga. Faktor ketidakdewasaan ini lebih nyata terdapat pada pasangan pernikahan di bawah umur. Menurut Walgito dalam bukunya yang berjudul Bimbingan Konseling Islam, bahwa perkawinan yang masih terlalu muda banyak mengundang masalah yang tidak diharapkan karena segi psikologisnya belum matang seperti cemas dan stress. ${ }^{27}$ Pernikahan bisa berdampak cemas, stress dan depresi. Yang terjadi di masyarakat Desa Makrampai Kecamatan Tebas pernikahan di bawah umur akibat hamil di luar nikah kebanyakan mengalami depresi, kecemasan, takut dan stress karena belum mengerti bagaimana dalam menjalankan kehidupan berumah tangga, karena pernikahan yang didasari dengan pergaulan bebas suka sama suka.

Secara pengamatan di Desa Makrampai Kecamatan Tebas Kabupaten Sambas Provinsi Kalimantan Barat, pernikahan pasca hamil jumlah terus bertambah banyak menimpa anak-anak sekolah mulai dari Sekolah Dasar (SD), Sekolah Menengah Pertama (SMP), Sekolah Menengah Atas (SMA). Pelaku ratarata teman dan pacarnya, pasangan suami-istri dari pernikahan ini terancam kerawanan masalah sosial ekonomi, masa depan keluarga (anak dan isteri) suram karena putus sekolah. Rentan perceraian dan kekerasan dalam rumah tangga (KDRT).Bagi keluarga pelaku (suami), pernikahan dispensasi hanya jadi upaya lari dari hukum. Bagi keluarga korban (perempuan), pernikahan di bawah umur adalah upaya untuk menutupi aib keluarga, itulah yang terjadi di Masyarakat Desa Makrampai Kecamatan Tebas Kabupaten Sambas Provinsi Kalimantan Barat.

Sehubungan dengan pernikahan di bawah umur di Desa Makrampai Kecamatan Tebas Kabupaten Sambas Provinsi Kalimantan Barat, dari pengamatan ini akan menghubungkan adanya faktor yang di jumpai di lapangan dan dalam kajian teoritis, maka ada faktor pendorong terjadinya pernikahan di bawah umur dan dampaknya dari adanya pernikahan di bawah umur selain dari hamil di luar nikah. Faktor-faktor pendorong pernikahan di bawah umur adalah sebagai berikut: ${ }^{28}$

${ }^{27}$ Walgito Bimo, Bimbingan dan Konseling Perkawinan, hlm. 20.

28 Maria Ulfa Subadio, Peranan dan kedudukan Wanita Indonesia, (Yogyakarta: UGM Press, 2004), hlm 147-148. 
1. Keinginan segera mendapatkan tambahan anggota keluarga.

2. Tidak adanya pengertian mengenai akibat buruk pernikahan di bawah umur, baik bagi wanita dan pria itu sendiri maupun keturunannya.

3. Sifat adat yang tidak mau menyimpang dari ketentuan-ketentuan adat.

Sedangkan terjadinya pernikahan di bawah umur menurut Hollean disebabkan oleh: ${ }^{29}$

1. Masalah ekonomi keluarga.

2. Orang tua dari gadis meminta persyaratan kepada keluarga lelaki apabila mau menikahkan anak gadisnya.

3. Bahwa dengan adanya pernikahan anak-anak tersebut, maka dalam keluarga gadis akan berkurang satu anggota keluarganya yang menjadi tanggung jawab (makanan, pakaian, pendidikan dan sebagainya).

Penjelasan di atas, akan menguraikan berdasarkan pengamatan di lapangan dari segi pengamatan penulis ada beberapa faktor yang mendorong sering dijumpai di lingkungan masyarakat Desa Makrampai Kecamatan Tebas Kabupaten Sambas Provinsi Kalimantan Barat, antara lain adalah:

1. Masalah ekonomi yang kian sempit.

2. Masalah Pendidikan Orang tua.

3. Masalah Pendidikan Anak.

4. Masalah Adat Istiadat

5. Married By Accident (MBA).

6. Pergaulan Bebas

7. Pengaruh Media Masa

8. Pengaruh Lingkungan

Perkawinan di bawah umur yang berada Desa Makrampai Kecamatan Tebas Kabupaten Sambas Provinsi Kalimantan Barat ini, dalam hal ini menegaskan bahwa calon mempelai terlalu terburu-buru dalam kehidupan memasuki kehidupan berumah tangga. Mereka tidak memperhatikan kesiapan fisik dan psikis yang menjadi modal utama berumahtangga.

Keadaan yang sangat rentan dengan resiko perkawinan di bawah umur atau pernikahan di bawah umur antara lain: ${ }^{30}$

1. Segi fisik

Dilihat dari segi fisik, pelaku pria belum cukup mampu dibebani suatu pekerjaan yang memerlukan keterampilan fisik untuk memperoleh penghasilan dan mencukupi kebutuhan ekonomi keluarganya. Padahal faktor ekonomi merupakan salah satu faktor yang berperan dalam kesejahteraan dan

${ }^{29}$ Suryono, Menuju Rumab Tangga Harmonis, (Yogyakarta: Liberti, 2007), hlm. 65.

30 Shinta Larasati Eddy Fadlyana, Pernikaban Dini dan Permasalahannya, Jurnal Sari Pediatri, Vol. 11 (Bandung: FK UNPAD, 2009), hlm 138. 
kebahagiaan rumah tangga. Bagi pelaku wanita akan dihadapkan pada pekerjaan rumah tangga yang tentu saja menguras tenaga terutama apabila mempunyai anak.

2. Segi mental

Pada umumnya, pelaku belum siap bertanggungjawab secara moral pada setiap apa saja yang menjadi tanggungjawab. Mereka sering mengalami goncangan mental karena masih memiliki mental yang labil dan belum matang dalam emosi.

3. Segi kesehatan

Dilihat dari segi kesehatan, pasangan ini rentan dengan resiko yang berkaitan dengan kesehatan reproduksi seperti kematian ibu maupun kematian bayi serta rendahnya derajat kesehatan ibu dan anak wanita di bawah umur tidak masuk dalam usia ideal hamil dan melahirkan melainkan beresiko tinggi. Segi kelangsungan rumah tangga kedewasaan yang kurang matang, labilnya emosional serta tingkat kemandirian yang rendah menyebabkan peluang perceraian besar. ${ }^{31}$

4. Segi Pendidikan

Terlalu muda usia menikah, maka rendah juga tingkat pendidikan yang dicapai oleh sang anak. Korelasi antara tingkat pendidikan dan usia saat menikah, semakin tinggi usia anak saat menikah maka pendidikan anak relatif lebih tinggi dan demikian sebaliknya.

Segi domestik

Ketidaksetaraan gender merupakan konsekuensi dalam pernikahan anak. Mempelai anak memiliki kapasitas yang terbatas untuk menyuarakan pendapat, menegosiasi keinginan berhubungan seksual, memakai alat kontrasepsi, dan mengandung anak. Demikian pula dari aspek domestik lainnya. Dominan pasangan seringkali menyebabkan anak rentan terhadap kekerasan dalam rumah tangga (KDRT) terutama perempuan yang berusia 16-18 tahun. ${ }^{32}$

Minimalisir dampak yang ditimbulkan oleh perkawinan di bawah umur maka dalam Penjelasan Umum Undang-Undang Nomor 1 Tahun 1974 Tentang perkawinan nomor 4 huruf (d) disebutkan bahwa perkawinan di bawah umur harus dicegah. Pencegahan ini semata-mata didasarkan agar kedua mempelai dapat memenuhi tujuan luhur perkawinan yang mereka langsungkan. ${ }^{33}$

Menurut dalam pencegahan dapat dilaksanakan dengan beberapa langkah, misalnya, melakukan sosialisasi tentang dampak pelaksanaan hlm. 36 .

${ }^{31}$ Labib MZ, Risalah, Nikah, Talak dan Rujuk, (Surabaya: Bintang Usaha Jaya, 2006),

32 Shinta Larasati Eddy Fadlyana, Pernikahan Dini dan Permasalabannya, Jurnal Sari Pediatri, Vol. 11 (Bandung: FK UNPAD, 2009), hlm 138.

33 Abdul Manan, Aneka Masalah Hukum Perdata Islam di Idonesia, Jakarta: Kencana, 2012), hlm. 11. 
pernikahan di bawah umur, menjelaskan pada masyarakat tentang hakikat pernikahan, merazia tempat-tempat gelap yang berpotensi menyebabkan tempat maksimal kaum remaja. Dan hal tersebut dapat dicapai dengan memaksimalkan lembaga pemerintahan dan swadaya masyarakat. Apalagi ini kasus rumah tangga yang hadapi di Kabupaten atau kota adalah tingginya angka perceraian yang ada saat ini. Menjadi pekerjaan rumah yang harus dituntaskan bagi pemerintahan untuk memberikan solusi menghambat derasnya tingkat perceraian. Karena pernikahan adalah ikatan yang suci antara laki-laki dan perempuan yang bertujuan untuk membangun keluarga sakinah, mawadah, warohmah.

Perbedaan karakter antara suami dan istri itu sangat-sangatlah manusiawi karena Allah menciptakan mahluk-Nya antara satu dan yang lain tidak ada kesamaan, oleh sebab itu dalam kehidupan rumah tangga kita perlu sabar dan saling mengerti antara suami dan istri sehingga akan tercapainya keluarga yang harmonis. Kecemasan-kecemasan yang timbul akibat gonjang-ganjing rumah tangga akan sedikit berkurang. Kita hidup memang perlu perjuangan tidak semua orang akan mengalami kesedihan terus menerus dan setiap orang juga tidak akan bahagia terus menerus, Allah menciptakan sesuatu di Dunia ini secara berpasang-pasang ada siang ada malam, ada sedih ada senang. Kita sebagai manusia hanya bisa berusaha dan berdoa apa yang sudah digariskan pada kita. Orang tua adalah orang yang sudah mengasuh, membesarkan, mendidik kita dari bayi hingga dewasa, jadi semua perkataan orang tua adalah do'a, kita sebagai anak hanya bisa berusaha mematuhi perintahnya karena surga berada di bawah kaki ibu.

\section{Solusi Pernikahan di Bawah Umur Akibat Hamil di Luar Nikah}

Melihat peranan orangtua sangat berpengaruh terhadap dampak psikologi pada anak dalam pernikahan di bawah umur ini, maka dari itu dengan wujud kepedulian kepada warga Desa Makrampai Kecamatan Tebas Kabupaten Sambas, Kantor Urusan Agama mengadakan penyuluhan yang ditujukan kepada orangtua dan anak-anaknya (remaja) dan kerjasama swadaya masyarakat untuk memberikan penyuluhan tentang penanggulangan pergaulan bebas anak remaja yang menyebabkan terjadinya pernikahan di bawah umur. Orangtua adalah komponen keluarga yang terdiri dari ayah dan ibu, dan merupakan hasil dari sebuah ikatan pernikahan yang sah yang dapat membentuk sebuah keluarga. Orangtua memiliki tanggungjawab untuk mendidik, mengasuh dan membimbing anak untuk mencapai tahapan tertentu yang menghantarkan anak untuk siap dalam kehidupan bermasyarakat.

Hak dan kewajiban antara orangtua dan anak-anak ini dalam UndangUndang Nomor 1 tahun 1974 diatur dalam pasal 45 sampai 47. Dalam pasal 45 ditentukan bahwa kedua orang tua wajib memelihara dan mendidik anak mereka dengan sebaik-baiknya, sampai anak itu menikah atau dapat berdiri sendiri. Disamping kewajiban untuk memelihara dan mendidik anak tersebut agar tidak 
terjadi pernikahan di bawah umur, orangtua juga menguasai anaknya yang belum mencapai umur 18 tahun atau belum pernah melangsungkan pernikahan. Kekuasaan orangtua ini meliputi juga untuk mewakili anak yang belum dewasa ini dalam melakukan perbuatan hukum di dalam dan di luar pengadilan (pasal 47).Sedangkan remaja adalah suatu usia dimana individu menjadi terintegrasi ke dalam masyarakat dewasa dimana suatu usia anak tidak merasa sama atau sejajar dengan orang dewasa.

Masa remaja adalah masa dimana remaja belum dewasa atau belum matang dalam periode perkembangan manusia antara masa puber dan pencapaian dewasa. Dengan alasan seperti itulah maka pihak KUA maupun pihak pemerintahan desa Makrampai kecamatan Tebas mengadakan penyuluhan bahaya pergaulan bebas dan pernikahan di bawah umur ditujukan langsung pada orangtua dan remaja dengan tujuan agar orang tua dan remaja bisa memahami hukum dan dampak dari pergaulan bebas dan pernikahan di bawah umur. Penyuluhan tersebut dilaksanakan dengan metode kelompok. Metode kelompok ini ditujukan pada orangtua dan remaja dengan tujuan agar mereka sadar dengan hukum yang berlaku di Indonesia dan bahaya yang akan terjadi khususnya bagi calon ibu yang mau melahirkan. Penyuluhan ini dilaksanakan tiga sampai empat bulansekali dengan tujuan mereka mau berangkat dan mau memperhatikan apa yang disampaikan. Dengan diadakan bimbingan tersebut, sedikit banyak masyarakat Desa Makrampai Kecamatan Tebas Kabupaten Sambas Provinsi Kalimantan Barat sudah banyak mengerti tentang bahayanya pernikahan di bawah umur, apalagi melihat pelaku pernikahan di bawah umur yang banyak mengalami dampak yang negatif. Mereka belajar dari pengalaman masyarakat yang melakukan praktek pernikahan di bawah umur banyak yang mengalami dampak yang negatif seperti depresi, kecemasan, ketakutan dan stres, akibat rumah tangganya yang tidak harmonis kebayakan masyarakat karena masalah ekonomi. Mereka hanya bisa pasrah dan berdoa semoga keadaan seperti ini akan cepat berakhir dan hari esok akan lebih baik dari hari-hari sebelumnya penyuluhan tersebut dilaksanakan dengan menggunakan fungsi penyuluhan konseling Islam antara lain:

Fungsi Preventif yaitu pencegahan, KUA dan pemerintahan desa Kecamatan Tebas melakukan penyuluhan yang ditujukan pada orangtua dan remaja yang akan melakukan pernikahan di bawah umur. Dengan tujuan agar para calon pelaku pernikahan di bawah umur sadar akan adanya hukum yang berlaku di Indonesia, dan akan lebih paham tentang bahaya pernikahan di bawah umur terutama bagi remaja perempuan yang melahirkan.

Fungsi kuratif pemecahan dalam hal ini dari pihak KUA dan pemerintahan desa membatu dalam memecahkan bagaimana supaya pernikahan di bawah umur agar tidak dilakukan oleh anak remaja di desa Makrampai, agar angka pernikahan di bawah umur berkurang tidak bertambah terus yaitu dengan cara mengadakan penyuluhan kepada orang tua dan remaja, yang dilakukan tiga 
sampai empat bulan sekali dilakukan dalam keadaan bertahap.

Fungsi developmental pengembangan yang dilakukan bagaimana penyuluhan pada orangtua dan remaja tidak berhenti begitu saja walaupun kadang banyak masyarakat Desa Makrampai yang menyepelekan masalah itu, tapi Bagaimana caranya dari pihak yang bersangkutan terus memperbaiki kekuranganya, agar masyarakat Makrampai antusias mengunjungi penyuluhan tersebut. Apalagi dalam penyuluhan itu tidak hanya terfokus dalam masalah pernikahan di bawah umur tapi menyangkut masalah dampak setelah pernikahan di bawah umur seperti yang sudah terjadi di Desa Makrampai yaitu depresi, cemas, ketakutan dan stress dalam membina rumah tangga.

\section{Penutup}

Pernikahan di bawah umur yang terjadi di Desa Makrampai Kecamatan Tebas Kabupaten Sambas Provinsi Kalimantan Barat merupakan kekhawatiran orangtua terhadap anak gadisnya yang terjerumus ke jurang kemaksiatan akibat pergaulan bebas, jadi pernikahan di bawah umur dianggap jalan keluar yang terbaik akibat hamil di luar nikah, walaupun anak itu belum mampu baik materi maupun psikologis untuk menempuh berumahtangga yang baik. Masalah kehidupan dalam rumah tangga bagi pasangan suami istri yang melangsungkan pernikahan dini pada umumnya disebabkan beberapa factor antara lain,masalah ekonomi yang kian sempit, masalah Pendidikan Orang tua, masalah Pendidikan Anak, masalah Adat Istiadat, married By Accident (MBA), pergaulan bebas, pengaruh Media Masa, pengaruh Lingkungan. Dampak psikologis dari pernikahan di bawah umur akibat hamil di luar nikah antara lain, depresi, cemas, ketakutan dan stress. Sesuai data yang ada maka dampak psikologi pernikahan di bawah umur yang terjadi di Desa Makrampai Kecamatan Tebas beberapa rumah tangga yang mengalami depresi, kecemasan, ketakutan dan stress yang terjadi karena tidak adanya keharmonisan dalam rumah tangga yang timbul karena sering terjadi percekcokan, cemburu yang berlebihan, adanya sikap keras suami terhadap istri, kurangnya pengetahuan istri terhadap pendidikan anak, mengurus anak, cara berbakti kepada suami, dan juga kurangnya sikap saling pengertian antara sesama. Orang tua harus memberikan pengertian dan motivasi agar anak tersebut mengenyam pendidikan yang lebih tinggi bukan malah dituruti kemauan seorang anak sehingga terjebak dalam pergaulan bebas yang berpotensi menyebabkan pernikahan di bawah umur, dalam menghindari hal tersebut agar tercipta suatu masyarakat yang berkualitas dalam menjalani kehidupan. Sebaiknya masyarakat yang mau melaksanakan pernikahan, mempertimbangkan usia perkawinan minimal umur 21 tahun untuk perempuan dan umur 25 tahun untuk laki-laki.al-Quran mengisyaratkan bahwa orang yang akan melangsungkan perkawinan haruslah orang yang siap dan mampu, serta dewasa. 


\section{Daftar Pustaka}

Al-Ghifari, Abu, Pernikahan dini Delima Generasi Ekstravagansa, Bandung: Rineka Cipta, 2002

Al-Khatîb, As-Syarbini, Muqhnî Al-Mubtâj. Beirut: Dâr ihya At-Turusi Al-Arabî. Jus II.

Al-Quran dan Terjemahannya, Departemen Agama Republik Indonesia, Pangeran Diponegoro, 2006

Anonimous, Kamus Besar Bahasa Indonesia, Jakarta: Balai Pustaka, Departemen Pendidikan dan kebudayaan, 1994

Basri, Hasan, Merawat Cinta Kasih, Yogyakarta: Pustaka Pelajar, 1996

Bety, Pernikahan Dini, Palembang: IAIN RADEN FATAH, 2013

Bimo, Walgito, Bimbingan dan Konseling Perkawinan, Yogyakarta: Yayasan Penerbitan Fak. Psikologi.UGM, 2000

Fadlyana, Eddy, Larasati, Shinta, Pernikahan Dini dan Permasalahannya, Jurnal Sari Pediatri, Vol. 11, Bandung: FK UNPAD, 2009

Husein, Muhammad, Fiqih Perempuan, Yogyakarta: LKIS, 2007

Madjab, Mahalli A, Menikablah Engkau Menjadi Kaya Kado Pernikaban Untuk Pasangan Muda), Yogyakarta: PT Mitra Pustaka, 2006

Manan, Abdul, Aneka Masalah Hukum Perdata Islam di Indonesia, Jakarta: Kencana, 2012

Mughniyyah, Jawad Muhammad, Al-Ahwâl Al-Syâkhsîyya, Beirut: Dâr Al Kutub Al 'Ilmiyâh,tt. terjemah. Sulaiman Al-Mufarraj

MZ, Labib, Risalah, Nikah, Talak dan Rujuk, Surabaya: Bintang Usaha Jaya, 2006

Rafeldi Mediaya, Kompilasi Hukum Islam dan Undang-undang Perkawinan, Wakaf, dan penyelenggaraan Haji, Jakarta: ALIKA, 2016

Rofiq, Ahmad, Hukum Perdata Islam di Indonesia, Jakarta: Rajawali Press, 2015

Sabiq, Sayyid, Fiqih Sunnah, (Terj) Moh Thalib jilid 6, Cet I, Jakarta: Al-Ma'arif, 1990

Sohari Sahrani,Tihami, Fikih Munakahat: Kajian Fikih Nikah Lengkap, Jakarta: Raja Wali Pers, 2010

Suryanah, A. Toto AF, Ibadah Praktis, Bandung: Sinar Harapan, 1995

Suryono, Menuju Rumah tangga Harmonis, Yogyakarta: Liberti, 2007.

Syarifuddin, Amir, Hukum Perkawinan Islam di Indonesia: Antara Fiqih Munakahat dan Undang-undangPerkawian, Jakarta: Prenadamedia 


\section{Group, 2014}

Ulfa Subadio, Maria, Peranan dan kedudukan Wanita Indonesia, Yogyakarta: UGM Press, 2004

Undang-Undang No. 1 Tahun 1974, Tentang Perkawinan dan Kompilasi Hukum Islam. Cet. 1, Surabaya: Sinarsindo Utama, 2015 
100 | Al-Istinbath: Jurnal Hukum Islam, Vol.4, No.1, 2019

\section{HALAMAN SENGAJA DIKOSONGKAN}

